\title{
Pollen and Spores from the Lower Cretaceous of Central Mongolia and Their Paleoclimatic Significance
}

\author{
Nyamsambuu Odgerel1 ${ }^{*}$, Niiden Ichinnorov², Adiya Eviikhuu ${ }^{3}$, Batsuren Tegshbayar ${ }^{4}$ \\ ${ }^{1}$ Department of Geology and Geophysics, National University of Mongolia, Ulaanbaatar, Mongolia \\ ${ }^{2}$ Institute of Paleontology and Geology, Mongolian Academy of Science, Ulaanbaatar, Mongolia \\ ${ }^{3}$ Uyan Geo Resource LLC, Ulaanbaatar, Mongolia \\ ${ }^{4}$ Sudalt Mana LLC, Ulaanbaatar, Mongolia \\ Email:*n.odgerel@num.edu.mn
}

How to cite this paper: Odgerel, N., Ichinnorov, N., Eviikhuu, A. and Tegshbayar, B. (2019) Pollen and Spores from the Lower Cretaceous of Central Mongolia and Their Paleoclimatic Significance. Open Journal of Geology, 9, 589-592. https://doi.org/10.4236/ojg.2019.910049

Received: August 15, 2019

Accepted: September 20, 2019

Published: September 23, 2019

Copyright (c) 2019 by author(s) and Scientific Research Publishing Inc. This work is licensed under the Creative Commons Attribution International License (CC BY 4.0).

http://creativecommons.org/licenses/by/4.0/

\begin{abstract}
The present study focuses on the Lower Cretaceous Khukhteeg Formation (Central Mongolia), which yields palynological assemblage that is used to understand the paleoclimate. Palynology samples from the Khovil opencast mine Choir-Nyalga Basin in the Central Mongolia have been analyzed for palynomorphs with SEM. The assemblage is dominated by pollen to conifers, such as Pinaceae, Podocarpaceae and Taxodiaceae, indicating the vegetation of conifer forests. The assemblage contains abundant spores Schizaeaceae, Cyatheaceae, which are generally associated with wet habitats. According to the detailed analyses, the plant community indicates that warm and humid subtropical paleoclimate controlled the study area during the Early Cretaceous.
\end{abstract}

\section{Keywords}

Khovil Opencast Mine, Lower Cretaceous, Khukhteeg Formation, Spore, Pollen, Mongolia

\section{Introduction}

Coal-bearing strata from Central Mongolia (Khukhteeg Formation) of Aptian to Albian age contain next to dominating Pinaceae, Cupressaceae pollen [1]-[5]. The Khovil opencast mine is located in Central Mongolia southeast of Ulaanbaatar in the Choir-Nyalga Basin. The Choir-Nyalga Basin is the result of extensional tectonics that was prevalent during the Lower Cretaceous north-south trending fold and thrust belt in the central of Mongolia [6] [7]. The sediments of the Khovil 
opencast mine belong to the lithostratigraphic unit of the coal-bearing Khukhteeg Formation which is, part of the Zuunbayan Group. The Khukhteeg Formation includes conglomerates, gravels, sandstones, and thick lignite coal [7].

\section{Material and Methods}

A total of 25 samples collected from Khovil opencast mine. The samples were treated with $\mathrm{HCl}$ and $\mathrm{HF}$ using standard palynological procedures then fossil pollen grains were investigated by scanning electron microscope (SEM). In Figure 1, SEM photos are presented.

\section{Results and Conclusion}

Palynological assemblage is characterized by the abundant of fern spores Cyathaceae and Schizaeaceae, Selaginellaceae, Lycopodiaceae and pollen Pinaceae, Podocarpaceae (Figure 1). In this assemblage, not observed spores Appendicisporites, very rare pollen Cedripites, contain chlorantahaceous angiosperms Clavatipollenites and unknown angiosperm pollen Retimonocolpites, Liliacidites-like, Platanus-like.

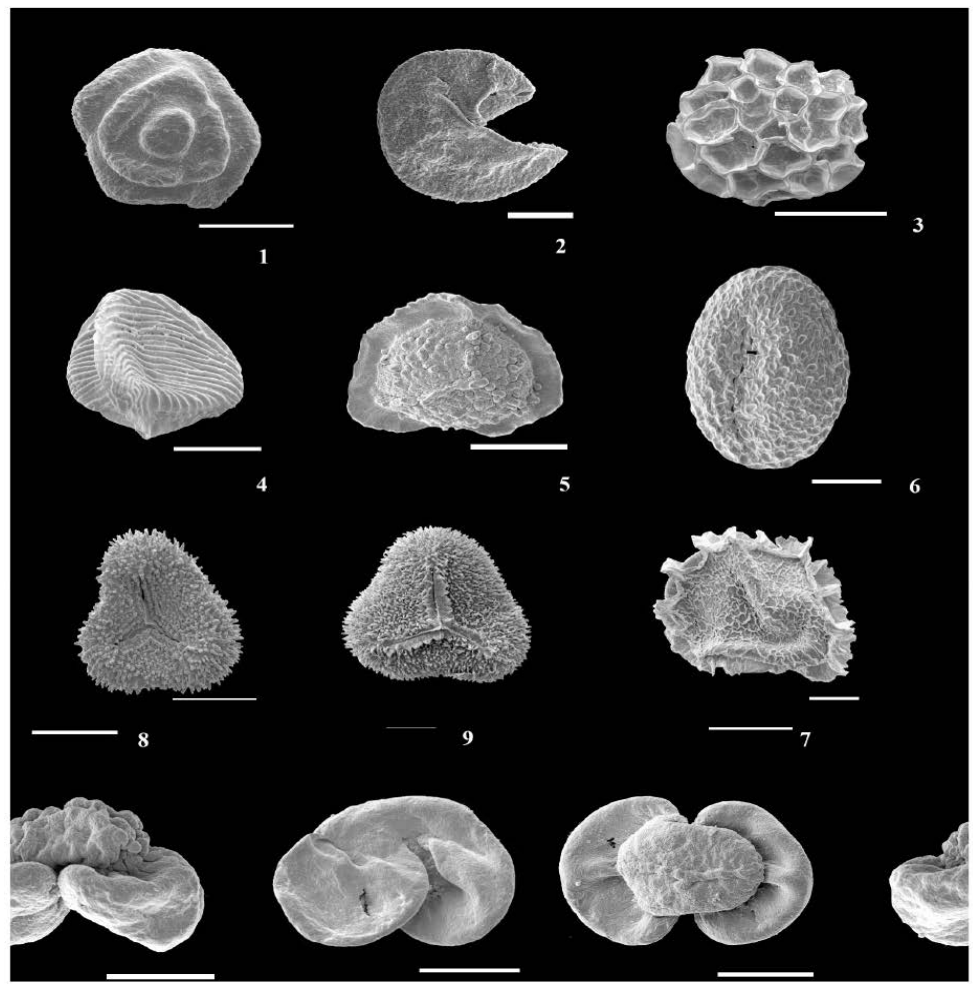

Figure 1. Spores and pollen from Khukhteeg Formation: (1) Taurocusporites reduncus, $5453 \times, 2 \mu \mathrm{m}$ (2) Taxodiaceaepollenites sp., 8830×, $10 \mu \mathrm{m}$ (3) Lycopodiumsporites marginatus, 6829×, $10 \mu \mathrm{m}$ (4) Cicatricosisporites dorogensis, 5907×, $20 \mu \mathrm{m}$ (5) Aequitriradites spinulosus, 4293×, $30 \mu \mathrm{m}$ (6) Schizosporis sp., 5907×, $50 \mu \mathrm{m}$ (7) Pilosisporites notensis, 5907×, $30 \mu \mathrm{m}$ (8) Pilosisporites sp., 5907×, $30 \mu \mathrm{m}$ (10) Lycopodium sp., 6829×, $10 \mu \mathrm{m}$ (10) Podocarpites luteus 3566×, $10 \mu \mathrm{m}$ (11) Podocarpites multisinus $3701 \times, 10 \mu \mathrm{m}(12)$ Piceapollenites sp., 2313×, $50 \mu \mathrm{m}$. 
This palynological assemblage is important for inferring paleoecological and paleoclimatic conditions of the region during the Early Cretaceous. The assemblage is dominated by pollen of conifers, such as Pinaceae, Taxodiaceae, indicating the vegetation of conifer forests. The assemblage contains abundant above mentioned pollen taxa, which are generally associated with wet habitats. The conifer plants grew on foothills at different distances from the lake, but Filicopsida dominated the lake shore. Clavatipollenites is also khown from lower latitudinal fossil localities (Spain, Portugal, Brazil, USA) and their presence in Mongolia might be evidence for the admixture of temperate and subtropical floras [8]. The Choir-Nyalga basin, which was a periodically ever-wet (presence of algal cysts, Botryococcus and liverworts Aequitriradites), low diverse peat producing environment situated in a more northern position at higher latitudes, where newcomers arrived later than at the lower latitudes.

\section{Acknowledgements}

We want to express our deep gratitude to Christa-Ch Hofmann (University of Vienna), Freddy Grimsson (University of Vienna) for improving the manuscript. Special thanks go to Altanzul Chikalov, Munkhnasan Otgon for outstanding fieldwork. This research has been supported by Ernst Mach Grant from the Austrian Federal Ministry of Education, Science and Research (BMBWF). This is a contribution to UNESCO/IUGS/IGCP 679 project.

\section{Conflicts of Interest}

The authors declare no conflicts of interest regarding the publication of this paper.

\section{References}

[1] Bratseva, G.M., Novodvorskaya, I.M. (1975) Spores and Pollen from the Lower Cretaceous Deposits of a Site Khuren-Dukh, MNR (Mongolian People's Republic). Fossil Fauna and Flora of Mongolia. Trudy Sovmestnaya Sovetsko-Mongolskaya Paleontologicheskaya, 2, 205-209.

[2] Matsukawa, M., Nagata, H., Taketani, Y., Khanda, Y., Khosbayar, P., Badamgarav, D. and Obata, I. (1997) Dinosaur Bearing Lower Cretaceous Deposits in the Choir Basin, S.E. Mongolia Stratigraphy and Sedimentary Environments. Journal of the Geological Society of the Philippines, 52, 99-114.

[3] Nichols, D.J., Matsukawa, M. and Ito, M. (2006) Palynology and Age of Some Cretaceous Nonmarine Deposits in Mongolia and China. Cretaceous Research, 27, 241-251.

[4] Saiki, K. and Okubo, A. (2006) Lower Cretaceous Flora of the Choyr Basin, Mongolia. Cretaceous Research, 27, 252-261.

[5] Shi, G.L., Leslie, A.B., Herendeen, P.S., Chinnorov, N., Takahashi, M., Knopf, P. and Crane, P.R. (2014) Whole Plant Reconstruction and Phylogenetic Relationships of Elatides zhoui sp. nov. (Cupresseaceae) from the Early Cretaceous of Mongolia. International Journal of Plant Sciences, 175, 911-930. https://doi.org/10.1086/677651

[6] Ito, M., Matsukawa, M., Saito, T. and Nichols, D.J. (2006) Facies Architecture and 
Paleohydrology of a Synrift Succession in the Early Cretaceous Choyr Basin Mongolia. Cretaceous Research, 27, 226-240.

[7] Erdenetsogt, B., Lee, I., Bat-Erdene, D. and Jargal, L. (2009) Mongolian Coal-Bearing Basins: Geological Settings, Coal Characteristics, Distribution and Resources. International Journal of Coal Geology, 80, 87-104. https://doi.org/10.1016/j.coal.2009.08.002

[8] Krassilov, V.A. (1982) Early Cretaceous Flora of Mongolia. Paleontolographica Abteilung $B, 181,1-43$. 